\title{
The Optimization of Library Services in the Elementary School
}

\author{
Asfi Mangzila \\ Department of Educational Administration \\ Universitas Negeri Malang, Indonesia \\ asfimangzila12@gmail.com
}

\section{Anjar Agus Firawati}

Department of Educational Administration

Universitas Negeri Malang, Indonesia

anjarfira@gmail.com

\author{
Anggraeni Cahyaningtyas \\ Department of Educational Administration \\ Universitas Negeri Malang, Indonesia \\ anggraenityas18@gmail.com \\ Quma Irah Larasati \\ Department of Educational Administration \\ Universitas Negeri Malang, Indonesia \\ qumairla7@gmail.com
}

\author{
Siti Munirotul Yuanita \\ Department of Educational Administration \\ Universitas Negeri Malang, Indonesia \\ munirotulyuanita@gmail.com
}

\begin{abstract}
The purpose of this system development is to restore and optimize the functionality of library services. The development method is a method of developing research. System development activities include book inventory; codification and labelling of books; book preparation; library space setup; and reward for "most frequent visitors" and "engraved borrowers". The results of this development make it easy for students to search for books, giving students the convenience to read in the library, and increasing student interest to visit the library.
\end{abstract}

Keywords: optimization library, inventory, codification, reward

\section{INTRODUCTION}

The ideal library is essentially a library capable of empowering the community. Libraries that are capable of performing a revolution in reading interest in society [1]. Able to change the community characters from dislike reading to be like reading. Transforming community information into communities that are iterating or information literate. For that an ideal library should have the following characteristics: a strong institutional structure; has an attractive space design; Have a varied collection according to the wishes of the settlers; Improved quality and quantity of librarians; and have quality services.

The processing of libraries in the library is the process of preparing the literature for use, immediately after the ticket of the library material in the libraries until it is hit on the shelf or elsewhere, ready to wear [2]. The process consists of inspecting the library materials, inventories, classifications, cataloguing, fixtures and drafting. The developer team is already implementing system development including inventory of books; codification and labelling of books; book preparation; library space setup; and reward for "most frequent visitors" and "engraved borrowers".

Inventory is one of the activities of registering books (collections of libraries) that are newly entered in the library, either obtained from purchases, gifts, grants, swinger or borrowed borrowing, must be recorded in the parent book or inventory library [2]. It aims to facilitate the drafting of reports on the development of collections owned by the library.

Classification comes from the word "classification" (English). The word "classification" derives from the word "to classify", meaning that it classifies and places the same objects somewhere [3]. Classification in the library is also intended to facilitate the user community in selecting and obtaining the necessary books or library materials quickly and precisely. For each book owned, the library must go through a classification process before being matched to the public. To do the classification process in the library, certain ways are the result of national and international agreements [4]. There are several classification systems used by libraries in the world, such as Dewey Decimal Classification (DDC), Universal Decimal Classification (UDC), Library of Congress Classification (LCC), Colon Classification (CC), etc.

Agency Library and the Bali Provincial Archives system used is Deway Decimal Classification system (DDC) because it is considered more practical. Dewey Decimal Classification (DDC) classification is the most popular and widely used classification chart in Indonesia. This chart was created by Melvil Deway (1851-1931). DDC is a chart of hierarchical system classification that adheres to the "decimal" principle in dividing the branches of science. DDC divides all knowledge into 10 main classes (Main Classes) which are given a notation in the form of Arabic numbers 000-900. Each main class is decimal divided into 10 sub classes (devision). Then the Sub class is divided again by decimal to 10 section, and so on. The subdivisions of the top 10 (Ten) classes are as follows: 000 computer science, general works information (Computer Information and Generalities); 100 philosophy and related discipline; 200 religion (religion); 300 social Sciences; 400 language; 500 pure Science; 600 Technology and Applied Sciences (Thecnology Applied Science); 700 arts, entertainment and Sports (The Arts); 800 literature (Literature); 900 history (General Geography and History) [4].

The book Label or call number is the number of books placed. The Label contains the qualification number, the first three letters of the author's name, the 
first letter of the book title. The Label is usually attached to the lower back of the book. How to manufacture are as follows [3]. The drafting or shelving is the final stage of the processing of the library material. The placement of collections on a bookshelf or a specific place is done so that users can browse the placement of the collection. Arranging the books of school libraries can use other ways of shooting several subjects in a single shelf or booklet. Please note that special reference books must be separated in placement, for example, thesis, Theses, Encyclopedia, Dictionary, Atlas.

Even if possible reference books are placed in a special room. If there is no special room should be placed in a shelf or a closet. An already advanced finest library that has many reference books, available space with enough to usually have a special space for reference equipped with a catalogue cabinet, table and Chair officer references, tables and chairs for pupils who will read the reference books. For reference books are not allowed to be brought home. If there is a pupil who needs to be read at the house of students can borrow to just in the photocopy directly returned on the day also [3].

The design of the building and library that will produce work that is efficient, convenient, and fun for library staff and "pemustaka" (user). Siregar [5], said that in order to produce a library that can be a workplace that is efficient, comfortable and enjoyable for library staff and visitors, the building or room of the library must be planned well in order to accommodate all the activities in the implementation of library functions according to the type of service, open (open access) or closed (closed access).

When the library closed system adopted, then the allocation is $45 \%$ for collection, $25 \%$ of users, $20 \%$ for staff and $10 \%$ for other purposes. If the system is open, then the allocation is governed by the distribution of $70 \%$ for collection and users, $20 \%$ of staff, and $10 \%$ for other purposes. Library infrastructure is the main supporting facility for the implementation of activities of library services. Infrastructure serves as the mechanism of providing library services to the service.

Completeness of the infrastructure needed to support the optimal level and usefulness of library services. Infrastructure to be a contributory factor to the success rate of utilization of services provided one of which is: the provision of chairs and a reading table. Students reading a book in a very influenced by the availability of a chair or a comfortable seat [6].

Moreover, in designing the library space should be considered in structuring a reading room, a collection of space and circulation space can be selected with the system partition, partition layout, and layout diffuse [7]. Bulkhead system is the way that puts the library room arrangement of separate collection of the reading room visitors.

This system does not allow visitors to get into space and the collection officer that will serve him. Interspace system is a system that puts the room settings of separate collections of the reading room. This system, allows the visitor to take his collection, then recorded and read in the other room. This system, allows the visitor to take his collection, then recorded and read in the other room. The diffuse system is a way of placing a collection that mixed with a reading room for the reader to more easily retrieve and restore its collection.

Circulation is one of the activities in the library that serves the borrowing, renewal and return of books. Circulation activities can be done after it has finished processing books complete with labels (there is a book card, book card pockets, tongue books and his call number). In general, circulation implies the circulation of library collections activities whether conducted in the library or out of the library.

There are several ways circulation service in the school library, namely: (1) system list (ledger system), the system uses the book folio double by creating columns for recording the date and loans, borrower name, address, title of the book, the codebook, dated back and initials; (2) bon systems (slip book), in this system, forms of borrowing can be written by the borrower. Bon is then stored by circulation clerk, when the book is returned, bon loan is taken and torn; and (3) card system, this system is the most modern, practical, but it is expensive and usually used for libraries that many borrowers [8].

Etymologically derived from English reward. A reward is a noun meaning a reward, gift, reward, reward [9]. In the Great Dictionary of Indonesian equivalent word to convey the same reward prize, which means gifts (memento, appreciation, respect) [10]. Revealed that the system of reward or reward to two categories are the most borrowers and the most frequent visitors to the students have undertaken the library of Semarang State Polytechnic in 2014 for Promotes increased interest in lending and library visits. And it turns out that succeeds and becomes a regular activity in the university which is held once every year [11].

In general, the purpose of the development of this system is to optimize and restore the function of the library service to run properly in the library Elementary School of Bareng 1 Malang. In particular goal of developing this system is to enable students to find books, provide comfort for students to read in the library, increasing student interest to visit the library, and curb the flow of processing of library materials and borrow back the library.

\section{METHODS}

Development of this system using the method development research on the function of the library service of Elementary School of Bareng 1 Malang, by using the waterfall model. Stages of the waterfall model include the step of requirements analysis, design, implementation and testing. The analysis explored the needs of the development of the library. This phase is done by direct observation and interviews with the school about the issues that need to be resolved and the needs required to optimize the process of development of the library.

Observations carried out directly in the library of Elementary School of Bareng 1 Malang, while the interviews conducted directly with the librarian. Once the needs of the development of the school library are known, it will be the design of library development. Implementation or preparation is carried out following the design of development that has been made so that the results can be following the purpose of optimizing the 
library. In this implementation will be explained how this program works so that the optimization function can be run properly library.

The final stage in the development the Elementary School of Bareng 1 Malang is the testing process. Testing is done to ensure that all library development process that has been done giving actual results to suit your needs. The final stage in the development of the Elementary School of Bareng 1 Malang is the testing process. Testing is done to ensure that all library development process that has been done giving actual results to suit your needs. The final stage in the development of the Elementary School of Bareng 1 Malang is the testing process. Testing is done to ensure that all library development process that has been done giving actual results to suit your needs.

\section{RESULTS}

The results obtained from this study are as follows: When developing the system in Elementary School of Bareng 1 Malang, the team found their new books coming in and have not been inventoried since the book was unopened and still in the box. When asked to the school librarian is indeed true that a newly purchased book has not conducted an inventory of the books. Therefore, the team conducted an inventory of premises do stamping book well seals the school library and stamp inventory on the home page book for members sign that the book had been entered and belongs to the school library of Elementary School of Bareng 1 Malang, then the team records the inventory book with the appropriate format.

Book classification process performed using the system Dewey Decimal Classification (DDC). The first stage is the selection of library materials. Librarians only allows coding of library materials fiction books that have not been coded. Previously, the library of Elementary School of Bareng 1 Malang has been codified, but not the entire book so that the development team to continue the rest of the book that has not been in the codification. Due to fiction books that have and have not coded fused into one, then perform the process of sorting the books are unlabeled and are already labelled. The next stage, these books do data collection of books from the title, the author's name, year of publication, publisher and city of publication.

The whole book is already in the data was then classified according to the subject is a schematic codification tenth of DDC that will facilitate the process of codification. After the book's label format then be made according to the rules of the school. Furthermore, library materials that have been adapted subjects were conducted codification by writing the number of suitably qualified in the DDC, the first name of the author last name and the first letter of the title of the book. Then the label is affixed to the spine $2 \mathrm{~cm}$ from the bottom of the book. and the first letters of titles. Then the label is affixed to the spine $2 \mathrm{~cm}$ from the bottom of the book. and the first letters of titles. Then the label is affixed to the spine $2 \mathrm{~cm}$ from the bottom of the book.

At Elementary School of Bareng 1 Malang book layout is irregular and does not match the classification so that the books, fiction books, and thematic books are mixed into one so that the development team improves the system by classifying books according to its subject.
The first step is to collect the books according to the subject. The drafting of the theme and thematic books are placed sequentially according to the class and theme sequences so that the layout of the book requires two elongated bookshelves. The arrangement of the theme and thematic books should be chosen first as most of the books on the shelf are unused and must include a new theme book.

For the new theme book, the team stamped on the book page then freshly placed on the shelf according to the class. Then for the textbook is arranged in a manner appropriate class level, ranging from Class 1 to grade 6 consisting of subjects of Indonesian language, English, Javanese language, mathematics, science, social science, cultural arts, criminal, and eyes Other lessons. The preparation of the textbook requires one elongated bookshelf. Furthermore, the fictional books that have been in the labelled were placed on the rear shelf according to the subject of the DDC codification to be easily sought by the learners. Then, after the entire library material is arranged in such a way, the last stage of the identification of the library material in each bookshelf consisting of 1-6 class thematic books, 1-6 class subjects and fictional books.

Updates read tables and chairs here is done by replacing the old table and chairs with a new one because the old tables and chairs that are less worthy because some parts of the seat there is a fragile and broken. Tables and chairs were replaced with new tables and chairs were better and made of plastic and iron were comfortable and durable and modern. Services circulation through the groove that starts from: the students into the library and then fills in the attendance list provided; student looking for a book to be desired; student reads the book in place provided; students borrow books to the clerk; students gave the book and student card to the clerk; officer noted books borrowed on the back of the book includes the date and loans, the date of return, and initialled the clerk and record books borrowed on the register and credit; officer gave the book and student card to the borrower; and the last student out of the library.

Different power conducted by a team of developers to Elementary School of Bareng 1 Malang this is the imposition of a system reward or appreciation to students who rated the most frequently visited libraries and also for learners who diligently to borrow books from the library resources. This is because before development by a team of developers, a library function in Elementary School of Bareng 1 Malang less than optimal as an example, many learners use her break time to play around in the library. Therefore, the development team took the initiative to provide new ideas for the library Elementary School of Bareng 1 Malang by imposing a system of rewards to student/ student are considered the most frequently visited libraries and also for students/student most often borrow books from the library resources.

It is certainly not just carried out by only giving gifts to student/student. However, the development team worked closely with librarians to record anyone student/student who often visited the library and borrow books at the library with a record in the visitor's book and book borrowers. This is done to make the motivation for students/student to be viable visit the library to read and 
borrow books from the library resources. The trial by the development team together with the librarian conducted before and after it provides socialization to student/student, with a trial period one week prior to socialize and 1 week after doing socialization and note that the trials that have been conducted by a team of developers can be managed significantly, this is shown through the attachment where before the trial regarding the procurement system of rewards, student/student who visited the library just a little bit and just play around in.

However, after the development team to test, visitors to the library have increased and more and more enthusiastic student/student to borrow a book. Table list of visitors can be seen in the attachment. The development team did not just give a gift only for development projects, but also useful for the next few weeks that can be used by librarians to make improvements to the library at Bareng 1 Elementary School Malang in order to attract students to frequent visits to the library to read or borrow books source of library. In connection with the return of the source book from the late library, the development team has agreed with the librarian that there will be a penalty of Rp. 500,- every 1 day that the fined fines will be used for other things useful for libraries.

\section{DISCUSSION}

Inventory is recording every incoming material library chronologically. From the book, it can be seen how many books have been included in a certain period, source and price of each book when purchased. In the library of Elementary School of Bareng 1 Malang has been conducting an inventory accordingly. While the inventory of activities undertaken includes: (1) giving seal or stamp on the parts of the book, which is part of the title page, a central courtyard and backyard. The importance of labelling or library stamp and stamp inventory on parts of the book is to mark or special character so well known that the book in question is the property of the library. Each book will be a collection of the library should be given the seal or stamp on the parts that are considered important; (2) provision of stamp inventory; and (3) registration number of books added to the parent/inventory.

A chart or on a schedule called Dewey Decimal Classification (DDC) consisting of a series of numbers for the main class notation statement called "header", for example 300 Economics (300 notations, economics is the header). In addition to the full chart, DDC (Dewey Decimal Classification) also has summaries, the summary pertamaa (10 premier class), a summary of the second (100 division) and a summary of the third (section 1000). The following illustration of the decimal: 000: Public Works; 100: LMU Philosophy and Psychology; 200: Religion; 300: Social Sciences; 400: Language \& Linguistics; 500: Pure Sciences (definitely/Nature); 600: Applied Sciences (Technology); 700: Arts, Entertainment, Sports; 800: Literature; 900: General Geography and History. On the development of the library system, codification is done in the library Elementary School of Bareng 1 Malang is following the theory of DDC (Dewey Decimal Classification) which has been codifying fiction book by using the code 800 (Literature), such for example the book Fiction Indonesia with code 813 books.
Book placement or book storage arrangement inside the shelf, done after the book is completed, so it can be directly used or loaned. In the library science given the term: "Shelving" which comes from the shelf with multiple shelves that means is a rack. Shelving placement or arrangement of books on the shelves. For libraries with an open system, the user can come to their library bookcase to select books to be borrowed or taken, it is best to book shelving are grouped according to the classification of books, which is precisely the subject according to the book. School libraries should be put on open systems, shelving books should be following the grouping of subjects. The codes are used to indicate the book or the call-number is following the classification system used.

For example, wearing a DDC system or the Dewey Decimal Classification, codes that will be used is a decimal number. The order of the work placement of books are as follows: to understand it well DDC classification code is a number between 000-999; books grouped by the code, meaning 000 into a class book, a book group 100 to one, class 200 to one and so on, until the class 900; in the class of $000,100,200,300$ and so on, each grouped in the same place, such as 000, 100, 110, 120 and so on. So check the classification number that has been in getting the job classification. Such placement will be flexible, as it can be inserted and plus and minus; if there are books that have the same classification number, then see the name of the author, to distinguish it.

How to prepare a book on the shelf/cupboard is as follows: books arranged on shelves in a state of standing, so the back of the book, where call-number can be included directly visible; in arranging, arranged from left to right on each shelf, and when it is full, move to the bottom, back from left to right, and so on; rack should not be met, to be easily added and removed his books; daoat book standard is used as a buffer to the book, so the book is not easy to collapse; each rack should be given instructions, lists of books on the subject of what golongab. On the development of the library system, the layout of the classification of library materials in the library do Bareng 1 Elementary School Malang are following the theory in which the development team has designed a neat layout and still give the impression of comfort to students.

Library infrastructure is the main supporting facility for the implementation of activities of library services. Infrastructure serves as the mechanism of providing library services to the service. Completeness of the infrastructure needed to support the optimal level and usefulness of library services. Infrastructure to be a contributory factor to the success rate of utilization of services provided one of which is: the provision of chairs and a reading table. Pemustaka reading a book in a very influenced by the availability of a chair or a comfortable seat [6].

On the development of the library system, renewal table and chairs reading done in the librar Bareng Elementary School 1 Malang are following the theory that where the development team has given the idea of the idea for the library at Bareng 1 Elementary School Malang form of renewal table and chairs reading for learners. Each of the students who visit the library is 
entitled to get the comfort of infrastructures while reading in the library. This is done in the hope that the development team of learners like to linger in the library to read a book from the library source.

Circulation is one of the activities in the library that serves the borrowing, renewal and return of books. Circulation activities can be done after it has finished processing books complete with labels (there is a book card, book card pockets, tongue books and his call number). In general, circulation implies the circulation of library collections activities whether conducted in the library or out of the library. There are several ways circulation service in the school library, namely: (1) system list (ledger system), the system uses the book folio double by creating columns for recording the date and loans, borrower name, address, title of the book, the codebook, dated back and initials; (2) bon systems (slip book), in this system, forms of borrowing can be written by the borrower. Bon is then stored by circulation clerk, when the book is returned, bon loan is taken and torn; (3) card system, this system is the most modern, practical, but it is expensive and usually used for libraries that many borrowers [8], on the development of the library system, the service is done at the library circulation Bareng 1 Elementary School Malang are in accordance with the theory in which the development team has given the idea for visitors to the library at Elementary School of Bareng 1 Malang to order in all respects. Each of the students who visit the library required to perform resource borrowing and returning books from the library following the procedures that have been applied. This is done in the hope that the development team allows users to use library materials handily.

Etymologically derived from English reward. A reward is a noun meaning a reward, gift, reward, reward [9]. In the Great Dictionary of Indonesian equivalent word to convey the same reward prize, which means gifts (memento, appreciation, respect) [10]. On the development of the library system, the different power given in the library Bareng 1 Elementary School Malang are in accordance with the theory in which the development team has given the idea of the idea for the library at Elementary School of Bareng 1 Malang form of implementation of the system of reward for each visitor who often visited libraries and visitors which often borrow books from the library resources.

\section{CONCLUSION}

From these discussions, it can be the result of the development of management systems specialized services library at Bareng 1 Elementary School Malang which is implemented by the group was successful and running well, this is evidenced from the codification and inventory book entry that can help librarians to organize books and made a note in ledger. The preparation of the layout of books and furniture layout that facilitates activities for visitors to find, read, borrow or return a book regularly and make a neat and clean room of the library so that the children feel comfortable when in the library. And providing rewards to students through class "borrowers most industrious" and "common visitors" to cultivate students interest to visit the library regularly.

\section{REFERENCES}

[1] Saputro, R. F. 2018. Menuju Perpustakaan Ideal: Sebuah Perpustakaan yang Memberdayakan. Retrieved April 24, 2019, from http://www.bpkp.go.id/pustakabpkp/index.php?p=perpusta kaan\%20ideal.

[2] Sinta. 2011. Pengolahan bahan pustaka Perpustakaan Perguruan Tinggi. Retrieved May 2, 2019, from https://sinta.unud.ac.id/uploads/wisuda/1221503010-3BAB\%20II.pdf.

[3] Bafadal, I. 2011. Pengelolaan Perpustakaan Sekolah. Jakarta: Bumi Aksara.

[4] Bangsawan, I. P. R. 2018. Panduan Penomoran Buku Menurut DDC. Jakarta: Barometer Mediatama.

[5] Siregar, B. 2008. Gedung dan Perlengkapan Perpustakaan. Medan: Program Studi Ilmu Perpustakaan Universitas Sumatera Utara.

[6] Murjito. 2011. Pembinaan Minat Baca. Jakarta: Universitas Terbuka.

[7] Lasa, H. S. 2009. Manajemen Perpustakaan. Yogyakarta: Gama Media.

[8] Muchyidin, A. S. 2014. Pelayanan Perpustakaan dengan Referensi untuk Perpustakaan Sekolah. Bandung: UPI.

[9] Echols, J. M., \& Shadily, H. 2008. Kamus InggrisIndonesia. Jakarta: Gramedia Pustaka Utama.

[10] Depdiknas. 2012. Kamus Besar Bahasa Indonesia. Jakarta: Gramedia.

[11] Suharso, P., \& Setyowulandari, Y. 2014. Strategi Pemberian Reward untuk Meningkatkan Minat Kunjung Mahasiswa di Perpustakaan Politeknik Negeri Semarang. Retrieved May 12, 2019, from https://r.search.yahoo.com/ ylt=AwrxgzN3j.Jb2WgAvhf3RQx.;ylu. 